\title{
Linda Giesel \\ Comparisons between Israel and Nazi \\ Germany in Contemporary German \\ Discourse
}

\section{Abstract}

Nazi comparisons are communicative strategies to express defamation against individuals or groups of people and to generate outrage in the space of public communication. Producers direct analogies toward the historical awareness of the recipients and furthermore anticipate their emotional reactions.

Since the beginning of the 1980s, we can determine that rhetorical dereferencing on the National Socialist (hereafter NS) past is made in connection with altercations concerning Israeli politics. In comparisons between National Socialists and Israelis, a correlation is established that defames the State of Israel as a continuity of the NS dictatorship. Apart from the relativization of National Socialism, the portrayal of the victims of the past as perpetrators of the present is furthermore a relativization of guilt. This form of imagination and interpretation discloses the desire for the relief from and resistance to culpability. It also services refusal of remembrance concerning the NS past, which is a functional element of antisemitism in the German post-Holocaust society.

In a linguistic corpus study that includes more than ten thousand emails, which were addressed to the Embassy of Israel in Berlin and the Central Council of Jews in Germany between 2002 and 2014, I analyzed verbal antisemitic Nazi comparisons, ${ }^{1}$ for example, "What Israel is doing with the annexation of Gaza is for me, personally, a form of a concentration camp!” (an email to the Embassy of Israel with reference to the Israel-Gaza conflict in 2014). Most of the emails with comparisons to Nazi Germany were sent during periods of military conflicts in the Middle East. However, writers constantly produce those derealizations, even during times of (military) de-escalation in the conflict.

1 This research was conducted within the project "Antisemitism in the World Wide Web" at the Technical University of Berlin (see https://www.linguistik.tu-berlin.de/fileadmin/fg72/Anti semitism_2.0_short_version_final.pdf) and financially supported by the German Research Foundation (DFG). Furthermore, parts of the corpus data are based on the research project "Conceptualization and Verbalization of Contemporary Antisemitism in Germany" by Monika SchwarzFriesel.

Ә OpenAccess. ( 2021 Linda Giesel, published by De Gruyter. (cc) BY-NC-ND This work is licensed under the Creative Commons Attribution-NonCommercial-NoDerivatives 4.0 International License. 
The systematic corpus-based study consists of quantitative evaluations as well as of qualitative analyses concerning the verbal realization of comparisons and antisemitic stereotypes. These results reveal that analogies between Israel and the German Nazi regime were realized predominantly as utterances without typical comparative connectives. These expressions address Israeli politicians in reference to different National Socialist officials, for example, Hitler and Goebbels, or the Israeli military in reference to Wehrmacht and SS. Those expressions focus primarily on the agents and frame them as perpetrators of the present. On the other hand, producers of Nazi comparisons also describe Palestinians as victims by referring to Gaza as the Warsaw Ghetto or Auschwitz. In my article, I present the results of this study and illustrate them by using examples of the corpus data.

\section{Introduction: Development and Function of Nazi Comparisons}

Since the post-war period, it can be determined that Nazi comparisons ${ }^{2}$ were used in and beyond Germany to equate politicians, practices, institutions, and crimes with entities and circumstances of the Nazi era to defame and stigmatize political opponents. Especially during the Cold War, analogies were drawn from both the Federal Republic of Germany and the German Democratic Republic to accuse each other of acting like the National Socialists or using their methods. ${ }^{3}$ In reference to constructing the Berlin Wall, the West German newspaper, Rheinische Post, described the GDR in 1961 as

(1) Ulbricht's large Concentration Camp. ${ }^{4}$

2 I use the term comparison in order to denote the common expression of Nazi comparison, even though they are heterogeneous comparisons. Those are basically characterized by drawing an analogy between two entities from different conceptual domains, for example, Anne is like a nightingale. Levinson denotes those utterances as "similes" in reference of figurative and heterogeneous comparisons. See S. C. Levinson, Pragmatics, 17th ed. (Cambridge: Cambridge University Press, 2006), 155.

3 Cf. G. Stötzel, “Zur Geschichte der NS-Vergleiche von 1946 bis heute,” Politische Semantik. Bedeutungsanalytische und sprachkritische Beiträge zur politischen Sprachverwendung, ed. J. Klein (Opladen: Westdeutscher Verlag, 1989), 266-67.

4 Rheinische Post, 17.08.1961; as quoted in T. Eitz and G. Stötzel, Wörterbuch der "Vergangenheitsbewältigung.” Die NS-Vergangenheit im öffentlichen Sprachgebrauch (Hildesheim: Olms, 2007), 1:404. 
Several politicians, for example, Willy Brandt, expressed similar statements concerning the lockdown of East Germany and the GDR citizens' escape attempts. ${ }^{5}$ Besides foreign affairs, Nazi comparisons were used in debates on domestic affairs to discredit politicians from the opposition party or in entirely other contexts, such as abortion or animal rights. ${ }^{6}$ They all have in common that they function as communicative strategies to express defamation against individuals or groups of people and to generate outrage in the space of public communication. ${ }^{7}$ Those analogies are directed toward the historical awareness of the recipients and, furthermore, anticipate their emotional reactions, ${ }^{8}$ because they refer to an era that represents inhumanity and terror like no other period of time. ${ }^{9}$

In the early years of using such phrases in political debates, right after World War II, there was no critical historic and linguistic reflection on them. It was not until the late 1960s that the first assessments on Nazi comparisons occurred, which marked them as "dangerous equation"10 and relativizations of the National Socialist past, as well as the violation of human rights. ${ }^{11}$ Despite the increased problematization of the use of those verbal strategies, there is also an increase of the usage of Nazi comparisons in international debates. Marie-Hélène Pérennec even describes this as "inflationary usage," 12 which is continually repeated in inner-German and international debates, for instance, the verbal attacks of the Turkish President, Recep Tayyip Erdoğan, in the spring of 2017 toward the Ger-

5 Cf. Stötzel, “Zur Geschichte der NS-Vergleiche von 1946 bis heute,” 267.

6 For example, the organization People for the Ethical Treatment of Animals (PETA) planed a campaign against factory farming by using the slogan "The holocaust on your plate" (cf. Eitz and Stötzel, Wörterbuch der "Vergangenheitsbewältigung," 1:350). On the other hand, Pro-Life activists have used the term "Babycaust" in reference to abortions since 1979. For further explanations, see L. Giesel, NS-Vergleiche und NS-Metaphern: Korpuslinguistische Perspektiven auf konzeptuelle, strukturelle und funktionale Charakteristika (Berlin: De Gruyter, 2019), 69-71.

7 Comparisons between entities of National Socialism and other entities, for example, the comparison between party programs of the NSDAP and the NPD, do not belong to the Nazi comparisons I discuss below. These are historically critical comparisons that serve as a form of sensitizing for (extreme) right-wing tendencies in political parties and not as defamations or demonizations of people or institutions.

8 Cf. M. Schwarz-Friesel, Sprache und Emotion, 2nd ed. (Tübingen: Francke, 2013), 197.

9 Cf. M. Schwarz-Friesel and J. Reinharz, Inside the Antisemitic Mind: The Language of Jew-Hatred in Contemporary Germany (Boston: University Press of New England, 2017), 134.

10 Die Zeit, 04.04.1969; as quoted in T. Eitz and G. Stötzel, Wörterbuch der "Vergangenheitsbewältigung.” Die NS-Vergangenheit im öffentlichen Sprachgebrauch (Hildesheim: Olms, 2009), 2:17.

11 Cf. Eitz and Stötzel, Wörterbuch der "Vergangenheitsbewältigung," 2:17-18.

12 M.-H. Pérennec, "Nazi-Vergleiche im heutigen politischen Diskurs: Von den Gefahren falscher Analogien,” LYLIA Lyon linguistique allemande 16 (2008): 11. 
man Government. He accused Germany of implementing "Nazi practices"13 against Turkish politicians and their planned campaigns in German cities. Erdoğan's statement hit the headlines for some weeks, and he primarily received rejection for his allegation. But the intended effect to cause a stir and to create outrage was successful.

Even though we can observe a large amount of Nazi comparisons in the past, they did not lose their effect over time: media attention. ${ }^{14}$ Thorsten Eitz and Georg Stötzel identify this attention as the main target of the producers. Many of them apologize for their utterances afterwards referring to an accidental faux pas. The procedure (from drawing the comparison to generating public outrage up to the apology) has become a "stereotype ritual." ${ }^{15}$ Despite the assertion that one has to deal with an accidental verbal error, Monika Schwarz-Friesel emphasizes that speakers use Nazi comparisons as an intentional strategy that forces a reaction of indignation. ${ }^{16}$

This article examines a specific type of Nazi comparison-the equation between Israeli entities and entities of the German Nazi era. Those expressions have special functions and impact on the context of the German post-Holocaust society. Before I define them as expressions of verbal antisemitism (part 3) and present some results of the corpus study (part 4), I will provide a short insight in verbal realization of Nazi comparisons from a linguistic point of view (part 2). This contribution is based on my research as part of the dissertation I submitted to the Faculty I (Humanities) at the Technical University Berlin in 2018.

\section{Verbal Realization of Nazi Comparisons}

Speakers use various verbal expressions to draw analogies between entities of the National Socialism and other entities. ${ }^{17}$ Besides formulating an explicit comparison and using like as connector, there are many ways to express equality or

13 “Bundesregierung verbittet sich Erdoğans Nazi-Vergleich,” Die Zeit, March 6, 2017, http:// www.zeit.de/politik/2017-03/tuerkei-recep-tayyip-erdogan-nazi-vergleich-reaktionen.

14 Cf. Eitz and Stötzel, Wörterbuch der "Vergangenheitsbewältigung," 1:3.

15 Ibid., 3-4.

16 Cf. Schwarz-Friesel, Sprache und Emotion, 198. If speakers use Nazi-specific vocabulary or phrases not knowing that they are drawing an analogy, for example, "to each their own" in different contexts, it can be assumed that this is an unintentional language use that exposes ignorance and unawareness of historical circumstances.

17 Comparisons and metaphors are based on analogies between two or more entities. For further explanation, see F. Eggs, Die Grammatik von als und wie (Tübingen: Narr, 2006), 66-67. 
similarity between two or more entities, for example, $X$ reminds me of $Y .^{18}$ Sometimes those analogies were drawn without using expressions that indicate the comparison; they are verbalized as nominal metaphors of the type $X$ is a $Y .^{19}$ In Nazi comparisons or metaphors, the entities are equated in terms of one or more qualities, characteristics that they allegedly have in common. This asserted common quality is referred to as tertium comparationis, which does not necessarily need to be expressed explicitly. ${ }^{20}$ The so-called third element of a comparison can also be inferred in the process of comprehension, ${ }^{21}$ for example in:

(2) Employees of Boehringer, who work in animal testing laboratories, are like Nazis from the history of Germany $[. . .]^{22}$

The recipient has to activate the general knowledge about characteristics of the behavior of National Socialists and apply them to employees of the pharmaceutical company Boehringer. In this way, the recipient establishes the conceptualization $^{23}$ CHEMicAl LABORATORY Assistants Acting Like NAZIS in the context of the utterance in 2). This creates an association between ANIMAL TESTING and NS CRIME, which suggests an equalization of the suffering of Nazi victims and the suffering of laboratory animals.

In addition to the variety of verbal indicators of comparison, there is also a diversity of entities that can be included in the comparison, such as persons, for example, Hitler or Nazi officials like Goebbels, institutions and organizations like the SS or the Wehrmacht, and crimes like the Shoah. Aside from explicit verbalizations, the comparisons can be expressed implicitly by the use of allusions or indirect utterances, such as:

18 Cf. L. Ortner, "Wortbildungs- und Satzbildungsmittel zum Ausdruck von Metaphern und Vergleichen in Science-Fiction-Texten oder: Von 'wurstförmigen Raumkrümmern' und 'Wesen wie Ameisenigel,'” in Studien zur deutschen Grammatik. Johannes Erben zum 60. Geburtstag, ed. E. Koller and H. Moser (Innsbruck: Institut für Germanistik an der Universität Innsbruck, 1985), 268.

19 Cf. H. Skirl and M. Schwarz-Friesel, Metapher, 2nd ed. (Heidelberg: Winter, 2013), 25-26.

20 Cf. Eggs, Die Grammatik von als und wie, 38-39.

21 Cf. ibid.

22 Quoted in TAZ, October 4, 2008, 30.

23 Conceptualizations can be described as mental images and mental representations. In cognitive linguistics, concepts are defined as mental units of organization that are memorized and processed with general knowledge in combination with subjective experiences (cf. M. SchwarzFriesel, Einführung in die kognitive Linguistik, 3rd ed. [Tübingen: Francke, 2008], 108-9). Following the standards of cognitive science, I use small capital letters to refer to conceptualizations. 
(3) Unfortunately the methods used are very similar to the bad times in our history (IBD_31.05.2010_Sch_019) ${ }^{24}$

For understanding of 3) it is necessary to infer the meaning of methods which were used in the bad times in our history. The comparison indicator similar establishes the analogy while the underspecified component bad times in our history implies the reference to Nazi Germany.

Although such expressions appear as comparisons on the linguistic surface with a characteristic structure, for example, comparison components and connectives, they basically fulfill different (cognitive and communicative) functions in contrast to "ordinary" comparisons, such as identifying differences and similarities of entities and thereby contribute to a gain of knowledge..$^{25}$ Pérennec determines that Nazi comparisons serve as a discursive practice that violates all conversational maxims ${ }^{26}$ and deliberately abuses the cognitive role of comparison. ${ }^{27}$ The functions that they fulfill in general is described in part 1 . There is one specific type of Nazi comparison that is an expression of contemporary antisemitism and additionally fulfills certain functions. This form will be discussed below.

\section{Comparisons between Israel and Nazi Germany as an Expression of Antisemitism}

Since the beginning of the 1980s, an increase of rhetorical dereferencing on the NS past in connection with altercations concerning Israeli politics can be determined. During this period, comparisons came especially from West German left-

24 This quote originates from an email to the Embassy of Israel in Berlin and belongs to the corpus data of the research project "Conceptualization and Verbalization of Contemporary Antisemitism in Germany” by Monika Schwarz-Friesel (for detailed information on this project and the specific corpus material, see Schwarz-Friesel and Reinharz, Inside the Antisemitic Mind). Based on that material, I analyzed emails with Nazi comparisons as part of my dissertation (see Giesel, NS-Vergleiche und NS-Metaphern).

25 The cognitve and comunicative functions of comparisons are described in Eggs, Die Grammatik von als und wie, 38, and in F. Eggs, "Vergleichen und Vergleiche-Implikationen der Sprachwissenschaft für die Sprachdidaktik," in Gesteuerter und ungesteuerter Grammatikerwerb, ed. T. Becker and C. Peschel (Baltmannsweiler: Schneider Verlag Hohengehren, 2006), 45-48. 26 The conversational maxims are compiled in H. P. Grice, "Logic and Conversation," in Syntax and Semantics, ed. P. Cole and J. L. Morgan (Cambridge: Academic Press, 1975), 3:47-48.

27 Cf. Pérennec, "Nazi-Vergleiche im heutigen politischen Diskurs,” 1. 
wingers in connection with the claiming of the Golan Heights in 1981 and with the Lebanon War in 1982. ${ }^{28}$ Rooted in the perception of anti-imperialistic antiZionism, which equates Zionism with Nazism, ${ }^{29}$ persons and groups from the left-wing spectrum were already drawing comparisons between Israel and Nazi Germany years before-in particular since the Six-Day War in $1967 .^{30}$ Since then, Israel was seen as a vicious oppressor country and imperial outpost of the United States in contrast to the Palestine Liberation Organization (PLO), which staged itself as part of a global social revolutionary liberation movement. It was supported by the anti-imperialistic internationally oriented left, which identified itself with the repressed Palestinians and positioned itself against the US and Israel. ${ }^{31}$

In 1969, immediately after an antisemitic attack of the Berlin Jewish Community Center at the remembrance event of the Pogrom Night from 1938, a claim of responsibility appeared, which was composed by the German Marxist organization "Schwarze Ratten/Tupamaros West-Berlin." 32 This attack had a special relevance in the context of antisemitic assaults because on the one hand, the assassins targeted German Jews and blamed them for military actions in the Middle East, while on the other hand, this crime was committed on a date that has such a painful historical implication like November 9; thereby it was directly connected to the victims of the Pogrom and their descendants. The authors who claimed responsibility provided reasons for the anti-Jewish terrorist attack and accused Israel of committing fascistic atrocities that would be equal to the "Kristallnacht von 1938":

28 Cf. Eitz and Stötzel, Wörterbuch der "Vergangenheitsbewältigung," 2:24.

29 An insight to anti-Zionism in connection with antisemitic concepts, also regarding the historical foundations, are given in L. Poliakov, Vom Antizionismus zum Antisemitismus, 2nd ed. (Freiburg: ça ira, 2006) and T. Haury, Antisemitismus von links: Kommunistische Ideologie, Nationalismus und Antizionismus in der frühen DDR (Köln: Hamburger Edition, 2002).

30 Cf. T. Stein, Zwischen Antisemitismus und Israelkritik. Antizionismus in der deutschen Linken (Wiesbaden: Verlag für Sozialwissenschaften, 2011), $45-47$.

31 Cf. M.W. Kloke, Israel und die deutsche Linke. Zur Geschichte eines schwierigen Verhältnisses, 2nd ed. (Frankfurt/Main: Haag und Herchen, 1994), 288.

32 During the commemoration, an explosion was supposed to injure and kill many people, especially Jews. However, because of an inoperable detonator, the prepared bomb did not explode. For details see, W. Kraushaar, Die Bombe im Jüdischen Gemeindehaus (Hamburg: Hamburger Edition, Institut für Sozialforschung, 2005). 
(4) [...] Every ceremony in West Berlin and in Germany suppresses that Zionists repeat the Kristallnacht from 1938 every day in the occupied territories, in refugee camps and in Israeli prisons. The Jews expelled from fascism have themselves become fascists [...]. ${ }^{33}$

In 4) the analogy is expressed through the iterative utterance repeating the Kristallnacht from 1938 as well as through the accusation of becoming themselves fascists. Thereby, the producers first refer to Zionists as NAZI PERPETRATORS and in the second sentence explicitly to Jews. Concealing the antisemitic intention with anti-Zionist expressions is a typical manifestation of anti-imperialistic antisemitism, which is revealed immediately in the text and certainly in the context of the crime.

In comparisons between National Socialists and Israelis, a correlation is established that stigmatizes the State of Israel as a continuation of the NS-dictatorship (becoming fascists). Apart from the extremely negative evaluation and defamation of Zionists and Jews, a relativization of National Socialism is expressed. It furthermore results in a portrayal of the Jewish victims of the past as perpetrators of the present. This reversal of perpetrators and victims serves the purpose of exoneration, which is one of the main functional elements of post-Holocaust antisemitism. ${ }^{34}$ Additionally, it is accompanied by a relativization of Germany's culpability in conjunction with the projection of guilt onto Israel and/or Jews. ${ }^{35}$ This form of hatred against Jews is often described as "antisemitism because of Auschwitz and not in spite of it." ${ }^{36}$ Concerning these dimensions of antisemitism, Schwarz-Friesel and Reinharz ascertain:

In fact, however, both dimensions are important if one wants to understand postwar antisemitism. Despite the Auschwitz experience, many Germans did not fundamentally alter their attitude toward Jews (and accordingly the traditional clichés remained in use in everyday discourse), and because of Auschwitz additional stereotypes developed based on denial of responsibility and repression of shame. ${ }^{37}$

33 Agit 883, 13.11.1969, 1. Jg., Nr. 40, 9, “Schalom + Napalm”; quoted in Kraushaar, Die Bombe im Jüdischen Gemeindehaus, 47.

34 Cf. W. Bergmann. “'Störenfriede der Erinnerung': Zum Schuldabwehr-Antisemitismus in Deutschland,” in Literarischer Antisemitismus nach Auschwitz, ed. K.-M. Bogdal, K. Holz, and M. N. Lorenz (Stuttgart: Metzler, 2007), 28-29, and A. Heyder, J. Iser, P. Schmidt, "Israelkritik oder Antisemitismus? Meinungsbildung zwischen Öffentlichkeit, Medien und Tabus," in Deutsche Zustände, ed. W. Heitmeyer (Frankfurt/Main: Suhrkamp, 2005), 3:149-50.

35 Cf. Schwarz-Friesel and Reinharz, Inside the Antisemitic Mind, 58.

36 Cf. D. Diner, "Negative Symbiose: Deutsche und Juden nach Auschwitz," in Ist der Nationalsozialismus Geschichte? Zu Historisierung und Historikerstreit, ed. W. Benz and D. Diner (Frankfurt/Main: Fischer-Taschenbuch-Verlag, 1987), 186.

37 Schwarz-Friesel and Reinharz, Inside the Antisemitic Mind, 58. 
Comparisons between Israel and Nazi Germany disclose the desire for the relief from and resistance to culpability in the German post-Holocaust society. ${ }^{38}$ They are to be considered as antisemitic utterances even if there is no explicit reference to Jews. Sometimes these comparisons are hidden as "criticism of Israel." However, this serves as a camouflage for covering underlying (antisemitic) thought patterns. In Israel-related antisemitism, the reference to the State of Israel (and not to Jews) functions as a projection surface of antisemitic conceptualizations. ${ }^{39}$

With respect to Nazi comparisons that do not refer to Israeli or Jewish entities (see parts 1 and 2), the utterances in this study are characterized by further features. Regarding the potency of Nazi comparisons concerning Israel, we can determine that in addition to their already persuasive potential, due to the impact on the historical consciousness (especially in a German context), ${ }^{40}$ they also manifest major elements of contemporary antisemitism: ${ }^{41}$ Comparisons between Israel and Nazi Germany serve to ward off guilt, they relativize NS crimes, and they function as "verbal antisemitisms"

\section{Corpus Study: Nazi Comparisons in Emails to the Embassy of Israel in Berlin and the Central Council of Jews in Germany}

To obtain a linguistically representative and systematic investigation of comparisons between Israel and Nazi Germany, I carried out a corpus study that included emails that were addressed to the Embassy of Israel in Berlin and the Central

38 Cf. Bergmann, “'Störenfriede der Erinnerung,” 28-29, and L. Rensmann, Demokratie und Judenbild. Antisemitismus in der politischen Kultur der Bundesrepublik Deutschland (Wiesbaden: Verlag für Sozialwissenschaften, 2004), 314.

39 Cf. W. Frindte and D. Wammetsberger, "Antisemitismus, Israelkritik, Nationalismus-Empirische Befunde," Berliner Debatte Initial 19, 1/2 (2008): 40; Stein, Zwischen Antisemitismus und Israelkritik, 34-36; Schwarz-Friesel and Reinharz, Inside the Antisemitic Mind, 153. They also outline the difference between legitimate criticism and anti-Israeli antisemitism as a verbal expression of violence (see 145-57).

40 Cf. Schwarz-Friesel, Sprache und Emotion, 197-99.

41 Cf. inter alia the "Working Definition of Antisemitism" constituted by the IHRA, May 2016, https://www.holocaustremembrance.com/sites/default/files/press_release_document_anti semitism.pdf, accessed February 1, 2021. Schwarz-Friesel and Reinharz, Inside the Antisemitic Mind, 23.

42 Ibid. 
Council of Jews in Germany between 2002 and 2014. I would like to thank Prof. Monika Schwarz-Friesel and Prof. Evyatar Friesel who kindly provided the data material for this study. During the investigation period, 10,235 emails in total had been received by both institutions. ${ }^{43}$

The corpus study allows a combination of a qualitative cognition-based linguistic textual analysis and a quantitative statistical analysis. The investigation of self-motivated written texts offers some advantages compared to other studies about antisemitic attitudes, for example, getting insights in individual conceptualizations and emotional patterns of the authors of the texts, without influencing them by the design and the conditions of the study concerning the formulation of the questions. ${ }^{44}$

In order to analyze any verbal manifestation of such analogies in the form of explicit and implicit comparisons, metaphors, and allusions, I selected each email that included at least one of those analogies and examined it according to certain linguistic criteria, such as the structure and components of the comparison or the metaphor (entities and tertia comparationis), lexical indicators, and connectives. ${ }^{45}$ In connection with the pattern of the Nazi comparison, I also annotated antisemitic stereotypes and descriptive or expressive lexemes of emotion mentioned in the email text. ${ }^{46}$ To analyze the empirical material, I

43 The precise period of emails to the Central Council includes March 31, 2002 to December 31, 2008 and to the Israeli Embassy includes October 17, 2003 to December 31, 2014. During this time 8,708 emails arrived at the Israeli Embassy, and 1,527 arrived at the Central Council.

44 See in detail Schwarz-Friesel and Reinharz, Inside the Antisemitic Mind, 327-30. For further information about research methods in the field of corpus linguistics, see N. Bubenhofer, Sprachgebrauchsmuster: Korpuslinguistik als Methode der Diskurs- und Kulturanalyse (Berlin: De Gruyter, 2009), 111-29, and C. Scherer, Korpuslinguistik, 2nd ed. (Heidelberg: Winter, 2014), $3-10$.

45 These linguistic categories are based on, inter alia, Ortner, "Wortbildungs- und Satzbildungsmittel zum Ausdruck von Metaphern und Vergleichen"; Eggs, Die Grammatik von als und wie and Eggs, "Vergleichen und Vergleiche," as well as on M. Thurmair, Vergleiche und Vergleichen. Eine Studie zu Form und Funktion der Vergleichsstrukturen im Deutschen (Tübingen: Niemeyer, 2001); M. Thurmair, "Vergleiche(n) im Text. Von der Wissensvermittlung zur Manipulation," LYLIA Lyon linguistique allemande 15 (2008): 1-18, and on F. Dornseiff, Der deutsche Wortschatz nach Sachgruppen. Mit einer lexikographisch-historischen Einführung und einer ausführlichen Bibliographie zur Lexikographie und Onomasiologie, 8th ed. (Berlin: De Gruyter, 2004).

46 These categories are based on, inter alia, Schwarz-Friesel, Sprache und Emotion; SchwarzFriesel and Reinharz, Inside the Antisemitic Mind; G. B. Ginzel, ed., Antisemitismus: Erscheinungsformen der Judenfeindschaft gestern und heute (Bielefeld: Verlag Wissenschaft und Politik, 1991); J. H. Schoeps and J. Schlör, eds., Antisemitismus: Vorurteile und Mythen (München: Piper, 1995), particularly N. Hortzitz, "Die Sprache der Judenfeindschaft," 19-40, and on Bergmann, “'Störenfriede der Erinnerung'." 
used a combination of inductive and deductive approaches, where the categories of the deductive analysis are based on linguistic and interdisciplinary antisemitism research. This framework was successively extended with inductive categories during the process of text coding, ${ }^{47}$ which was technically realized by using the qualitative analysis tool MAXQDA. ${ }^{48}$

Due to this approach, it is possible to gain results about the frequency of emails with Nazi comparisons corresponding with the addressed institutions, while regarding the time period on the one hand and gaining a qualitative view into the thought patterns, underlying the comparisons on the other hand. In connection with the qualitative analysis, linguistic conclusions about drawing analogies and different forms of verbal realization also could be achieved. In the following sections, I present selected results of my examination and illustrate them by using examples of the corpus data. ${ }^{49}$

\subsection{Quantitative Results}

The evaluation of all 10,235 emails sent to the Embassy of Israel in Berlin and the Central Council of Jews revealed 945 (9.2\%) texts that include comparisons between Israel and Nazi Germany in any form of verbal realization (see part 4.2). A total of $8.8 \%$ of those texts were addressed to the Embassy and $11.5 \%$ of them were addressed to the Central Council. A correlation between the institution and the frequency of emails with those analogies can be determined, but this correlation is very weak. ${ }^{50}$ The fact that Israel-related Nazi comparisons were sent to the Central Council, an institution that represents the Jewish community in Germany, illustrates that German Jews were held accountable for circumstances in the Middle East or for Israeli practices. In the mind of the writers

47 Cf. F. Breuer, Reflexive Grounded Theory: Eine Einführung für die Forschungspraxis, 2nd ed. (Wiesbaden: Verlag für Sozialwissenschaften, 2010).

48 This is a software for qualitative, quantitative, and mixed methods data analysis, cf. U. Kuckartz, Einführung in die computergestützte Analyse qualitativer Daten, 3rd ed. (Wiesbaden: Verlag für Sozialwissenschaften, 2010), 12-20.

49 The corpus design and the research methods as well as the results of the study are described in detail in Giesel, NS-Vergleiche und NS-Metaphern, 160-301.

50 The chi-square test reveals a correlation between the frequency of emails with Nazi comparisons and the institution (Embassy vs. Central Council as the independent variable), $\chi 2=11.26$. The Cramér's V, which is based on $\chi 2$, shows only a weak effect, $V=0.033$. Cf. C. Duller, Einführung in die Statistik mit EXCEL und SPSS. Ein anwendungsorientiertes Lehr- und Arbeitsbuch, 2nd ed. (Heidelberg: Physica-Verlag, 2007), 128-29. 
of these emails, the central council of Jews in Germany functions as a representative of the Israeli state as the following examples show:

(5) You behave worse than the NAZIs [...] you build walls, kill children and enslave and spoil the rest of humanity (ZDJ_27.07.2006_Zaj_001)

(6) Your settlement policy in the Middle East is nothing other than what Adolf Hitler unfortunately did from 1933 to 1945. (ZDJ_29.07.2006_Boe_001)

The Council is directly addressed (you) and connected with Israel's policy toward the Palestinians. Besides the stereotypes of ChILd Murderer, OpPressive AND Illegitimate STATE, and THe Evil IN THE WoRLD, Nazi comparisons in this context reveal a conceptual pattern which is associated with the antisemitic stereotype of Jews ARE ISRAELIS AND DO NOT BELONG TO THE GERMAN SOCIETy. This is the current variant of the traditional Judeophobic stereotype of JEwS AS THE OTHER AND FOREIGNERS:

This fundamental categorization, which originated in antiquity, provides the foundation for all further stereotypes. Without this differentiation or discrimination, the negative attributions derived from it would not exist in such massive proportions. Only comprehensive exclusion of a certain social group makes it possible to focus on features deemed to set it apart. One generally ascribes positive characteristics to one's own group in order to reinforce one's identity and self-concept..$^{51}$

The analysis of the time period, in which these emails were received, reveals that between 2006 and 2014 most of the texts with comparisons to Nazi Germany were sent during periods of military confrontations in the Middle East. ${ }^{52}$ The years in which a military conflict between Israel and the Palestinian territories or Lebanon took place, like the war against the Hezbollah (2006), the military operations Cast Lead (2009), ${ }^{53}$ Pillar of Defense (2012), and Protective Edge (2014), show $22.4 \%$ more emails than years without major military operations (2007, 2008, 2010, 2011 and 2013). ${ }^{54}$ In contrast, the amount of emails with Nazi comparisons displays only a very small difference: $9.9 \%$ of the emails dur-

51 Schwarz-Friesel and Reinharz, Inside the Antisemitic Mind, 75.

52 Because of the total quantity and the balance of the data material during the whole evaluation period, only the frequencies of the emails to the Israeli Embassy were included in the calculation.

53 Operation Cast Lead started already on December 27, 2008. However, the emails that refer to it were only received from the beginning of 2009.

54 The absolute frequencies are 5,318 emails during the years with military conflicts and 3,370 emails during the years without military escalation periods. 
ing periods of conflict include Nazi comparisons, and 7.2\% of emails during military de-escalation times contain such utterances. ${ }^{55}$

This result demonstrates that Nazi comparisons concerning Israel were produced consistently, no matter if there was a military conflict or not. This finding indicates the stability of those derealizations ${ }^{56}$ and their associated antisemitic conceptualizations, which were activated with, as well as without, the reference to specific military confrontations. The example in 7) is taken from a text that was sent to the Embassy during the Operation Pillar of Defense, and 8) is an email with reference to specific Israeli politicians but without any information about a specific discourse:

(7) The Israeli state is a killer state. What is the difference between this state and the German terror system from 33-45? You do not need to be surprised that Jews are hated. (IBD_17.11.2012_ano_002)

(8) HEIL HEIL NETANJAHU! HEIL LIEBERMAN. JEW NAZIS!!!!!!!!!!!!!

(IBD_29.04.2011_Did_001)

Both analogies serve the functions of Nazi comparisons even though they are constructed completely different, and they contain different entities. The next paragraph outlines several aspects of the verbal realizations of such expressions.

\subsection{Dominant Manifestations of Verbal Realization}

The qualitative analysis shows that analogies between Israeli entities and Nazi entities are predominantly realized as comparisons. From 1,021 analogies, ${ }^{57}$

55 In some cases other discourse events may have occurred that also took place within these periods of time. In order to get comparable intervals and to detect an overall tendency of the distributions of emails including Nazi comparisons, this possible interference factor was accepted.

56 Schwarz-Friesel and Reinharz define derealizations as "linguistic utterances [which; L. G.] do not portray reality as it is (and can be intersubjectively experienced), but rather constitute, on the basis of their semantic contents, the language generators' own subjective realities. In this case, the representational function of language, which depends largely on the criterion of truth (and the possibility of testing a thing's truth value), is instrumentalized by the language generators to verbalize aspects of the world as they view them," Schwarz-Friesel and Reinharz, Inside the Antisemitic Mind, 158.

57 For the reason that some emails include more than one analogy, 1,021 of those expressions were determined in 945 emails to the Israeli Embassy and the Central Council of Jews in Germany. 
$77.8 \%$ are expressed in a comparison and $22.2 \%$ in a metaphorical structure. In addition to typical comparative connectives, for example, like in 9), the analyzed Nazi comparisons are mainly verbalized by different terms that indicate the comparison between two or more entities, in 10)-15)..$^{58}$

(9) Your home country is a torturer like the Nazis!!!!!!!!!!!!!!!!!!!!!! (ZDJ_17.01.2008_ano_001)

In utterances without explicit connectors, producers often express Nazi comparisons by negating a difference between Israel and Nazi Germany or by accusing Israel of not being any better than the National Socialists.

(10) what you are doing is not different from what the Nazis did !!! (IBD_00.00.2014_Süs_001)

(11) Especially you Jews who had many victims in World War II, must be ashamed of such deeds. You are not better than Adolf Hitler and his followers (IBD_31.05. 2010_Bra_002)

In allegations like 11), the imagination emerges that Jews should have learned from the NS-history and therefore should act in an outstanding moral way. Furthermore, this conceptualization is one of the dominant (post-Holocaust) stereotypes that are connected to Nazi comparisons. In addition to the negation of a difference between Israel and Nazi regime, many comparisons are verbalized by comparative lexemes like similar, comparable, parallel or the same.

(12) I have to say that Israel acts totally inhumanly. Why are they doing similar things that happened during the Holocaust to other peoples now? (ZDJ_27.07.2006_Hun_001)

Besides the comparative lexeme in 12), we can also determine the adverb now which serves as a temporal deictic expression. Lexemes and phrases like back in time, then, former, or in the past in opposition to now, today, or currently can also function as comparison indicators:

(13) What former used to be the Warsaw Ghetto is the Gaza Strip today. The Nazis were against the Jews and the Israelis (Jews) today are against the Palestinians. (IBD_09.01.2011_Fri_001)

58 The following list of verbal realizations is based on dominant forms I carried out in the course of the corpus study. Due to the scope and the focus of this article, I will present selected verbal manifestations. 
Another expression for Nazi comparisons is the focus particle also, which emphasizes the tertium comparationis as the focused element of the comparison. ${ }^{59}$ The focus particle establishes an analogy relation between the entities by indicating an allegedly common feature, like being people of perpetrators:

(14) The Holocaust was cruel and bad, but always presenting oneself as a victim is very blatant. You are also a perpetrator. (IBD_10.09.2012_Fri_001)

In 14) it is not only the focus particle that serves as indicator of the (implicit) Nazi comparison. The reversal of victims and perpetrators is also expressed. Even though all antisemitic Nazi comparisons imply a reversal of perpetrators and victims, there are some manifestations that explicitly frame the victims of the past, their descendants, and/or Israelis (as citizens of a state of the Shoah survivors) as perpetrators of the present. In the following excerpt of an email, addressing the military operation Cast Lead, the reference to guilt and shame fits into the conceptual representation of the perpetrator-victim reversal:

(15) The state of Israel, which is a cruel one, must now be ashamed because it is guilty. Victims become perpetrators. (IBD_22.01.2009_Gar_001)

The projection of guilt onto Israel and/or Jews is accompanied by a relativization of Germany's culpability. As explained in part 3, expressions like that constitute a current manifestation of post-Holocaust antisemitism.

A different way to draw analogies between Israel and Nazi Germany is to use typical Nazi vocabulary, for example, Heil in greetings to the ambassador or the prime minister of Israel:

(16) The Jews call Heil Hadas Handelsman (IBD_01.07.2013_ano_001)

(17) I have heard that the Israelis greet each other with Heil Netanjahu (IBD_20.10. 2012_ano_001)

When a specific lexeme or a citation is used to refer to a situation other than the original one, it is a form of allusion from a semantic-functional point of view. ${ }^{60}$ Writers also use popular phrases, for instance, known from the Sportpalast

59 Concerning the German auch, see G. Helbig, Lexikon deutscher Partikeln, 2nd ed. (Leipzig: Verlag Enzyklopädie, 1990), 91-92.

60 Cf. P. Lennon, "Die Rolle von Anspielungen in britischen Zeitungstexten," Zeitschrift für Angewandte Linguistik 34 (2001): 14. 
speech of Joseph Goebbels (1943) in reference to military conflicts in the Middle East:

(18) Does Israel want the total war? (IBD_27.11.2012_Amm_001)

Israel is being accused of intending to start an ethnic (total) war or to plan a genocide of the Arab population, which is labeled as the final solution/Endlösung. The following example is also verbalized as a rhetorical question and refers to the Lebanon war in 2006:

(19) Is the disproportionate use of tanks, air force and bombs already the final solution? (IBD_28.06.2006_Jae_001)

As indirect speech acts, rhetorical questions do not intend answers; they primarily function as assertives that express an assertion and an evaluation in an implicit way ${ }^{61}$ Nevertheless, to use specific expressions of the Nazi vocabulary has a special function: because of their historical relevance and the associated memories, the emotional dimension of these expressions is very important. ${ }^{62}$ The utterances in 18) and 19) express an equation between the concepts Israeli Military Operation and World War II or the Shoah. For the reason of this direct equation of the entities, the analogies show intersections with nominal metaphors like the examples below. Here Gaza is conceptualized as a concentration camp, Benjamin Netanyahu as Adolf Hitler and Israel's policy as Holocaust to the Palestinians.

(20) The idea to bombard the Gaza concentration camp with phosphorus bombs may have been taken directly from Nazi textbooks (IBD_00.06.2010_Not_001)

(21) Netanyahu the HITLER of the Jewish land. Liebermnan the henchman (IBD_00.05. 2010_ano_044)

(22) Stop the holocaust of Palestinian people!!! STOP THIS genocide!!! (ZDJ_15.01. 2009_Kay_001)

Using words like Holocaust or concentration camp in different contexts causes a referential shift of their original meanings. ${ }^{63}$ Concerning the term Holocaust,

61 Cf. J. Meibauer, Pragmatik: Eine Einführung, 2nd ed. (Tübingen: Stauffenburg Verlag, 2008), 109.

62 The emotional potential of antisemitic texts is described in Schwarz-Friesel and Reinharz, Inside the Antisemitic Mind, 208-34.

63 Cf. ibid., 138. 
Soric determines a successive abstraction of the word meaning that leads to a detachment of the reference to the mass murder of the European Jews. ${ }^{64}$ Schwarz-Friesel and Reinharz criticize this as a (ahistorical) decontextualization, which functions in a way that those words

no longer allude to the unique historical events and stages of the Nazi genocide but are employed as defamatory tools directed against Jews or Israelis. Thus the communicative strategy of perpetrator-victim reversal is mirrored on the verbal microstructural level with a derealizing effect. ${ }^{65}$

In addition to the question of realizing the analogy, the components of the comparison were also analyzed as part of the study. The results reveal that comparisons and metaphors with components referring to Israeli entities prevail (72.7\%) over components referring explicitly to Jewish entities (20.8\%). Concerning the basis of the comparison, which contains the concept related to National Socialism, two groups of entities can be identified. On the one hand, these comparisons refer to agents such as Adolf Hitler, Nazis in general and individual Nazi officials, like Goebbels, Himmler, and Eichmann, or specific NS institutions and organizations, such as NSDAP, Wehrmacht, and the SS. Those expressions focus primarily on the actors and frame them as perpetrators of the present. ${ }^{66}$

(23) I can no longer identify any significant difference between the Israeli army and the German Wehrmacht in the attack on Poland in 1939

(ZDJ_31.07.2006_Sch_001)

On the other hand, producers of Nazi comparisons refer to Gaza as the Warsaw Ghetto or Auschwitz and declare the Israeli Palestine policy as Holocaust or final solution. ${ }^{67}$ These utterances either focus on Palestinians explicitly or imply the conceptualization of them as victims of the Israeli state which applies Nazi methods.

(24) Gaza, the largest concentration camp worldwide

(IBD_00.06.2010_Wik_001)

64 Cf. A. Soric, “'Bomben-Holocaust': Eine sprachkritische Analyse eines kontroversen Ausdrucks mit rechtsextremistischem Hintergrund," Aptum: Zeitschrift für Sprachkritik und Sprachkultur 2 (2005): $178-87$.

65 Cf. Schwarz-Friesel and Reinharz, Inside the Antisemitic Mind, 138.

66 See also examples 5)-11) and 21).

67 See also examples 12), 13), 19), 20), and 22). 
Another way to draw analogies between Israel and Nazi Germany is, as shown in part 2, to express it implicitly by the use of utterances like the past, the terrible history, or:

(25) Evil thoughts would compare this situation with 70 years ago ... (IBD_03.12.2012_Bus_001)

Recipients infer the meaning of such phrases by activating their background knowledge within the communicational contexts. The analogy is established by the lexeme compare and the underspecified component 70 years ago implies the reference to Nazi Germany. Due to the fact that Nazi comparisons are controversial and often rejected in the space of public communication, we can assume that the writer attempts to indicate a distance from the expression by referring to evil thoughts and by using the subjunctive would compare.

\section{Conclusion}

Comparisons, which are ordinarily cognitive instruments of achieving knowledge by contrasting or identifying similarities of characteristics of entities, change their function when they are realized as Nazi comparisons. This article revealed those expressions as verbal strategies of defamation, demonization, and relativization of National Socialism as well as phenomena of contemporary antisemitism when it comes to the equation of Israel and Nazi Germany. The reversal of perpetrators and victims (and their descendants), and the projection of guilt onto Israel, which underlies such utterances, serves the purpose of exoneration, one of the main functional elements of post-Holocaust antisemitism.

The corpus study indicated that emails including Nazi comparisons were sent to the Embassy of Israel as well as to the Central Council of Jews in Germany in a similar frequency, whereas the relative amount of Nazi comparisons addressed to the Central Council is slightly higher (11.5\% vs. 9.2\%). The results reveal that producers, who send these texts referring to Israel to the Central Council, which acts as representation of German Jews, conceptualize JEwS AS IsRAELIS AND Not Belonging to the GeRman Society. This represents the current variant of the traditional Judeophobic stereotype of Jews AS GROUP OF THE OTHER AND AS FOREIGNERS.

Emails including those analogies were sent during periods of military conflicts as well as during times of no military altercations. This leads to the conclusion that Nazi comparisons were produced constantly and regardless of whether there was a military conflict occurring in the Middle East. The periods of military 
confrontation can, for example, act as a form of valves for antisemitic expressions, but they are no trigger for antisemitism. Among other verbal manifestations, this illustrates the stable "mental system of belief and [...] interpretation of the world" 68 as a typical constant of antisemitism.

The analysis of linguistic forms of the analogies between Israel and the German-Nazi regime reveals a variety of verbalizations. ${ }^{69}$ They are realized predominantly as utterances without typical comparative connectives, also as metaphors, as allusions through specific NS vocabulary or through implicit phrases. Producers of Nazi comparisons mainly focus on agents like Israelis and/or Jews, Israeli institutions and politicians or Jewish organizations and equate them with National Socialist entities. Furthermore, they refer to Gaza as Warsaw Ghetto or concentration camp and the Palestine policy as Holocaust. By the use of those verbalizations, writers explicitly or implicitly characterize Palestinians as Current Victims of the Israeli Nazi Regime. In addition to the antisemitic impact, these demonizations express a banalization of the genocide of the European Jews and the Nazi era in general; they mock the victims of the National Socialists as well as their descendants. The exposure of a language usage that trivializes Nazi crimes is of course of utmost relevance-not only from a linguistic perspective but also from a historical and socio-political point of view. Concerning an uncritical handling of those verbal attacks, Schwarz-Friesel and Reinharz warn:

When drastic expressions [...] and comparisons to the Nazis are used repeatedly for socalled criticism of Israel without being challenged, after a while their inappropriateness goes unnoticed and habituation sets in. ${ }^{70}$

Research studies identified the high frequency of the usage of Nazi comparisons in multiple contexts within the public and in the private space of communication. ${ }^{71}$ Regarding specific comparisons between Israel and Nazi Germany, the tendency of habituation is also determined in this corpus analysis. Detecting such language usage and its implications should have the aim of raising aware-

68 Schwarz-Friesel and Reinharz, Inside the Antisemitic Mind, 18.

69 A detailed classification of the verbal realization is given in Giesel, NS-Vergleiche und NSMetaphern, 196-245.

70 Schwarz-Friesel and Reinharz, Inside the Antisemitic Mind, 13.

71 Cf. Among others Stötzel, "Zur Geschichte der NS-Vergleiche von 1946 bis heute," 261-76; Eitz and Stötzel, Wörterbuch der "Vergangenheitsbewältigung," vol. 1 and vol. 2; Pérennec, "Nazi-Vergleiche im heutigen politischen Diskurs," 1-12; Soric, “"Bomben-Holocaust,"” 178-89. Schwarz-Friesel, Sprache und Emotion, 197-200; Schwarz-Friesel and Reinharz, Inside the Antisemitic Mind, 344-45. 
ness of the dangers that are in involved in it, especially considering the current political tendencies and the increase of Israel-related antisemitism. ${ }^{72}$

Linda Giesel is a linguist whose research focuses on hate speech, contemporary antisemitism, and Nazi comparisons. During her doctoral studies, she was part of the DFG-project "Antisemitism in the World Wide Web" at the Technical University of Berlin. In 2019 she published her dissertation on the topic of Nazi comparisons and metaphors with a focus on structural, conceptual, and functional characteristics of antisemitic utterances from a corpus linguistic perspective. Her current work focuses on investigating antisemitism in the context of the penal system in Germany.

\section{Bibliography}

\section{Primary Sources}

Emails to the Embassy of Israel in Berlin and the Central Council of Jews in Germany between 2002 and 2014. Research Project: "Conceptualization and Verbalization of Contemporary Antisemitism in Germany" at the Technical University of Berlin, see: Schwarz-Friesel, M. and J. Reinharz. Die Sprache der Judenfeindschaft im 21. Jahrhundert. Berlin: De Gruyter, 2013. / Inside the Antisemitic Mind: The Language of Jew-Hatred in Contemporary Germany. Boston: University Press of New England, 2017.

Agit 883, November 13, 1969, "Schalom + Napalm." 1. Jg. Nr. 40, 9. Quoted in Die Bombe im Jüdischen Gemeindehaus, edited by Wolfgang Kraushaar, 47. Hamburg: Hamburger Edition, 2005.

Rheinische Post, August 17, 1961. Quoted in Wörterbuch der Die NS-Vergangenheit im öffentlichen Sprachgebrauch. Die NS-Vergangenheit im öffentlichen Sprachgebrauch, edited by Thorsten Eitz and Georg Stötzel, 1:404. Hildesheim: Olms, 2007.

TAZ, October 4, 2008. “Kampf mit langen Unterhosen,” 30. T08/OKT.00539. Cosmas II, Institut für Deutsche Sprache Mannheim. http://www.ids-mannheim.de/cosmas2/. Accessed November 15, 2017.

Die Zeit, "Bundesregierung verbittet sich Erdoğans Nazi-Vergleich.” March 6, 2017. http:// www.zeit.de/politik/2017-03/tuerkei-recep-tayyip-erdogan-nazi-vergleich-reaktionen.

Die Zeit, April 4, 1969. Quoted in Wörterbuch der "Vergangenheitsbewältigung." Die NS-Vergangenheit im öffentlichen Sprachgebrauch, edited by Thorsten Eitz and Georg Stötzel, 2:17. Hildesheim: Olms, 2009.

72 For more details, see the development of antisemitic attitudes in A. Zick and A. Klein, Fragile Mitte, Feindselige Zustände: Rechtsextreme Einstellungen in Deutschland 2014 ed. for the Friedrich Ebert Foundation by R. Melzer (Berlin: Dietz, 2014), 68-72; A. Zick, B. Küpper, and D. Krause, Gespaltene Mitte - Feindselige Zustände: Rechtsextreme Einstellungen in Deutschland 2016, ed. for the Friedrich Ebert Foundation by R. Melzer (Berlin: Dietz, 2016), 47-48. 


\section{Secondary Sources}

Bergmann, Werner. “'Störenfriede der Erinnerung': Zum Schuldabwehr-Antisemitismus in Deutschland." In Literarischer Antisemitismus nach Auschwitz, edited by Klaus-Michael Bogdal, Klaus Holz, and Matthias N. Lorenz, 13-35. Stuttgart: Metzler, 2007.

Breuer, Franz. Reflexive Grounded Theory: Eine Einführung für die Forschungspraxis. 2nd ed. Wiesbaden: Verlag für Sozialwissenschaften, 2010.

Bubenhofer, Noah. Sprachgebrauchsmuster: Korpuslinguistik als Methode der Diskurs- und Kulturanalyse. Berlin: De Gruyter, 2009.

Diner, Dan. "Negative Symbiose: Deutsche und Juden nach Auschwitz." In Ist der Nationalsozialismus Geschichte? Zu Historisierung und Historikerstreit, edited by Wolfgang Benz and Dan Diner, 185-97. Frankfurt/Main: Fischer-Taschenbuch-Verlag, 1987.

Dornseiff, Franz. Der deutsche Wortschatz nach Sachgruppen. Mit einer lexikographisch-historischen Einführung und einer ausführlichen Bibliographie zur Lexikographie und Onomasiologie. 8th ed. Berlin: De Gruyter, 2004.

Duller, Christine. Einführung in die Statistik mit EXCEL und SPSS. Ein anwendungsorientiertes Lehr- und Arbeitsbuch. 2nd ed. Heidelberg: Physica-Verlag, 2007.

Eggs, Frederike. Die Grammatik von als und wie. Tübingen: Narr, 2006.

Eggs, Frederike. "Vergleichen und Vergleiche-Implikationen der Sprachwissenschaft für die Sprachdidaktik." In Gesteuerter und ungesteuerter Grammatikerwerb, edited by Tabea Becker and Corinna Peschel, 45-62. Baltmannsweiler: Schneider Verlag Hohengehren, 2006.

Eitz, Thorsten, and Georg Stötzel. Wörterbuch der "Vergangenheitsbewältigung." Die NS-Vergangenheit im öffentlichen Sprachgebrauch, vol. 1. Hildesheim: Olms, 2007.

Eitz, Thorsten, and Georg Stötzel. Wörterbuch der "Vergangenheitsbewältigung." Die NS-Vergangenheit im öffentlichen Sprachgebrauch, vol. 2. Hildesheim: Olms, 2009.

International Holocaust Remembrance Alliance. "Working Definition of Antisemitism." Issued May 26, 2016. Accessed February 1, 2021. https://www.holocaustremembrance.com/ sites/default/files/press_release_document_antisemitism.pdf.

Frindte, Wolfgang, and Dorit Wammetsberger. "Antisemitismus, Israelkritik, NationalismusEmpirische Befunde." Berliner Debatte Initial 19, nos. 1-2 (2008): 29-42.

Giesel, L. NS-Vergleiche und NS-Metaphern: Korpuslinguistische Perspektiven auf konzeptuelle, strukturelle und funktionale Charakteristika. Berlin: De Gruyter, 2019.

Ginzel, Günther B., ed. Antisemitismus: Erscheinungsformen der Judenfeindschaft gestern und heute. Bielefeld: Verlag Wissenschaft und Politik, 1991.

Grice, H. Paul. "Logic and Conversation." In Syntax and Semantics, edited by Peter Cole and Jerry L. Morgan, 3:41-58. Cambridge: Academic Press, 1975.

Haury, Thomas. Antisemitismus von links. Kommunistische Ideologie, Nationalismus und Antizionismus in der frühen DDR. Köln: Hamburger Edition, 2002.

Helbig, Gerhard. Lexikon deutscher Partikeln. 2nd ed. Leipzig: Verlag Enzyklopädie, 1990.

Heyder, Aribert, Julia Iser, and Peter Schmidt. "Israelkritik oder Antisemitismus?

Meinungsbildung zwischen Öffentlichkeit, Medien und Tabus.” In Deutsche Zustände, edited by Wilhelm Heitmeyer, 3:144-65. Frankfurt/Main: Suhrkamp, 2005.

Hortzitz, Nicoline. "Die Sprache der Judenfeindschaft." In Antisemitismus: Vorurteile und Mythen, edited by Julius H. Schoeps and Joachim Schlör, 19-40. München: Piper, 1995.

Kloke, Martin W. Israel und die deutsche Linke. Zur Geschichte eines schwierigen Verhältnisses. 2nd ed. Frankfurt/Main: Haag und Herchen, 1994. 
Kraushaar, Wolfgang. Die Bombe im Jüdischen Gemeindehaus. Hamburg: Hamburger Edition, Institut für Sozialforschung, 2005.

Kuckartz, Udo. Einführung in die computergestützte Analyse qualitativer Daten. 3rd ed. Wiesbaden: Verlag für Sozialwissenschaften, 2010.

Lennon, Paul. "Die Rolle von Anspielungen in britischen Zeitungstexten.” Zeitschrift für Angewandte Linguistik 34 (2001): 5-25.

Levinson, Stephen C. Pragmatics. 17th ed. Cambridge: Cambridge University Press, 2006. Meibauer, Jörg. Pragmatik: Eine Einführung. 2nd ed. Tübingen: Stauffenburg Verlag, 2008. Pérennec, Marie-Hélène. "Nazi-Vergleiche im heutigen politischen Diskurs. Von den Gefahren falscher Analogien." LYLIA Lyon linguistique allemande 16 (2008): 1-12.

Poliakov, Léon. Vom Antizionismus zum Antisemitismus. 2nd ed. Freiburg: ça ira, 2006.

Ortner, Lorelies. "Wortbildungs- und Satzbildungsmittel zum Ausdruck von Metaphern und Vergleichen in Science-Fiction-Texten oder: Von 'wurstförmigen Raumkrümmern' und 'Wesen wie Ameisenigel'." In Studien zur deutschen Grammatik. Johannes Erben zum 60. Geburtstag, edited by Erwin Koller and Hans Moser, 255-75. Innsbruck: Institut für Germanistik an der Universität Innsbruck, 1985.

Rensmann, Lars. Demokratie und Judenbild. Antisemitismus in der politischen Kultur der Bundesrepublik Deutschland. Wiesbaden: Verlag für Sozialwissenschaften, 2004.

Scherer, Carmen. Korpuslinguistik. 2nd ed. Heidelberg: Winter, 2014.

Schoeps, Julius H. and Joachim Schlör, eds. Antisemitismus. Vorurteile und Mythen. München: Piper, 1995.

Schwarz-Friesel, Monika. Einführung in die kognitive Linguistik. 3rd ed. Tübingen: Francke, 2008.

Schwarz-Friesel, Monika. Sprache und Emotion. 2nd ed. Tübingen: Francke, 2013.

Schwarz-Friesel, Monika, and Jehuda Reinharz. Inside the Antisemitic Mind: The Language of Jew-Hatred in Contemporary Germany. Boston: University Press of New England, 2017.

Skirl, Helge, and M. Schwarz-Friesel. Metapher. 2nd ed. Heidelberg: Winter, 2013.

Soric, Aleksandar. “'Bomben-Holocaust': Eine sprachkritische Analyse eines kontroversen Ausdrucks mit rechtsextremistischem Hintergrund." Aptum: Zeitschrift für Sprachkritik und Sprachkultur 2 (2005): 178-89.

Stein, Timo. Zwischen Antisemitismus und Israelkritik. Antizionismus in der deutschen Linken. Wiesbaden: Verlag für Sozialwissenschaften, 2011.

Stötzel, Georg. "Zur Geschichte der NS-Vergleiche von 1946 bis heute.” In Politische Semantik. Bedeutungsanalytische und sprachkritische Beiträge zur politischen Sprachverwendung, edited by Josef Klein, 261-76. Opladen: Westdeutscher Verlag, 1989.

Thurmair, Maria. Vergleiche und Vergleichen. Eine Studie zu Form und Funktion der Vergleichsstrukturen im Deutschen. Tübingen: Niemeyer, 2001.

Thurmair, Maria. "Vergleiche(n) im Text. Von der Wissensvermittlung zur Manipulation." LYLIA Lyon linguistique allemande 15 (2008): 1-18.

Zick, Andreas, and Anna Klein. Fragile Mitte - Feindselige Zustände: Rechtsextreme Einstellungen in Deutschland 2014. Edited for the Friedrich Ebert Foundation by Ralf Melzer. Berlin: Dietz, 2014.

Zick, Andreas, Beate Küpper, and Daniela Krause. Gespaltene Mitte - Feindselige Zustände: Rechtsextreme Einstellungen in Deutschland 2016. Edited for the Friedrich Ebert Foundation by Ralf Melzer. Berlin: Dietz, 2016. 